\title{
DOEKEN VOOR EEN DODE VORST
}

Mede door bemiddeling en grote betrokkenheid van Pauline Lunsingh Scheurleer zijn de verzamelingen van Museum Volkenkunde in Leiden op 16 september 2008 verrijkt met een tweetal grote schilderingen uit Bali, uit het bezit van de Vereniging van Vrienden van Instituut Kern (inventarisnummers $12546-7$ en 12546-8). ${ }^{1}$ Omdat beide auteurs van dit artikel zich op verzoek van Pauline al afzonderlijk hadden verdiept in de achtergrond van deze doeken, is besloten voor dit speciale afscheidsnummer voor Pauline hierover gezamenlijk een artikel te schrijven. In het eerste deel bespreekt Francine haar onderzoek naar de verzamelcontext van de doeken. Hierbij wordt een vergelijking gemaakt met de collectie van het Nationaal Museum in Jakarta, waarmee Pauline in het kader van het project Shared Cultural Heritage ook heeft samengewerkt. Rapti richt zich vervolgens in het tweede gedeelte op de iconografie van de schilderingen.

In het jaarverslag 1930-1933 van Instituut Kern staat het volgende: 'Met bijzondere dankbaarheid vermelden wij één groote en twee kleinere geschilderde doeken uit Bali, welke aan het Instituut Kern zijn ten geschenke gegeven door Mevrouw de Wed. R.S. van Stenis-James. Reeds vroeger had de heer H.T. Damsté ons verheugd met een dergelijk kleurig Balineesch kunstwerk van grooten omvang, waarvan thans is vastgesteld dat het op de sage van den strijd om den nektar betrekking heeft. Als een merkwaardige omstandigheid zij hier nog vermeld dat de twee groote doeken dienst hebben gedaan bij dezelfde plechtigheid, namelijk de crematie van den Rijksbestierder Goesti Djilantik.'2

Dankzij deze 'merkwaardige omstandigheid', het gebruik van de doeken bij een ritueel dat zo belangrijk was dat er verslagen en foto's van gepubliceerd werden, is de herkomst van de schilderingen achterhaald, en van een van beide doeken zelfs de precieze locatie tijdens het ritueel. Deze informatie is uitzonderlijk voor oude Balinese schilderingen in museumcollecties. Bovendien is gebleken dat ook het Nationaal Museum in Jakarta al sinds 1916 in het bezit is van twee bijzondere doeken voor dezelfde dode vorst. De aanwinst van de schilderingen heeft daardoor voor Museum Volkenkunde nog meer betekenis gekregen.

\section{De crematie van I Gusti Gde Djelantik}

Op 1 oktober 1916 werd I Gusti Gde Djelantik, de oude vorst van Karangasem, Oost-Bali, tijdens een grootse ceremonie gecremeerd. Het uitgebreide ritueel werd georganiseerd door zijn neef I Gusti Bagus Djelantik, die zijn oom in 1908 als 'Stedehouder' van Karangasem was opgevolgd. ${ }^{3}$ De overleden vorst 
stond op goede voet met het Nederlands-Indische gouvernement. Wegens zijn optreden tijdens de Lombokoorlog in 1894 was hij 'beloond' met de relatief zelfstandige functie van stedehouder van het voormalige rijkje Karangasem.

Voor de crematie van de vorst, die in april 1916 op 78-jarige leeftijd was overleden, waren tientallen Europeanen uitgenodigd. Schilder Leo Eland schreef in een ooggetuigenverslag in "De Reflector", geillustreerd weekblad voor Nederlands-Indië: 'Reeds maanden tevoren werden door regeering en dagbladen op de belangrijkheid der crematie van bovengenoemden vorst gewezen en werden belangstellenden aangespoord tot een gang naar Bali." Ook in de bestuursvergadering van het Bataviaasch Genootschap op 3 juli 1916 werd aandacht besteed aan de 'plechtigheid der verbranding in October a.s. van het lijk van I Goesti Gde Djlantik. Deze plechtigheid zal vermoedelijk wel de grootste zijn, die nog op Bali plaats zal vinden.' Dr. F.D.K. Bosch en H.J.E.F. Schwartz kregen het verzoek 'zich daarheen te begeven en van deze gelegenheid gebruik te maken om de verzamelingen van Bali in het Museum aan te vullen. ${ }^{5}$ Bosch was hoofd van de Oudheidkundige Dienst, tevens bestuurslid van het Bataviaasch Genootschap, en Schwartz was sinds 1915 adjunct-conservator van de belangrijke etnografische afdeling van het Museum in Batavia. Bosch werd vergezeld door H.L. Leydie Melville, een archeoloog die ook foto's maakte voor de Oudheidkundige Dienst (OD).

Een crematieritueel van iemand van hoge adel (palebon) is op Bali nog steeds een spectaculaire gebeurtenis, die geworteld is in de religie van bijna de gehele Balinese bevolking, de Agama Hindu Dharma. ${ }^{6}$ Deze godsdienst is ontstaan door hindoeïstische en boeddhistische invloeden op inheemse geloofsvoorstellingen. Baliërs geloven in reïncarnatie, die pas kan plaatsvinden als het crematieritueel is uitgevoerd. Door de verbranding kan het stoffelijk lichaam, dat wordt beschouwd als microkosmos, terugkeren naar de elementen van de macrokosmos, zodat de ziel wordt bevrijd. Door het uitvoeren van een crematie worden de plichten van de familie tegenover de doden vervuld, hoewel er, soms jaren later, nog andere zuiveringsrituelen voor de ziel (mukur, maligia) op moeten volgen. Omdat de ceremonie heel kostbaar is, vinden er vaak gemeenschappelijke lijkverbrandingen plaats, en armere mensen kunnen deelnemen aan een belangrijke crematie van bijvoorbeeld een vorst, zodat hun doden kunnen delen in het effect van het belangrijke ritueel. Een vorstelijke crematie verhoogt het prestige van de directe familie, en kan alleen worden uitgevoerd met hulp van vele betrokkenen. In het geval van de ceremonie voor Gusti Djelantik werd het ritueel ook gehouden voor zijn twee maanden tevoren overleden echtgenote. Toen Eland op 29 september samen met ongeveer 60 andere Europeanen met het s.s. Pynacker Hordijk op Bali arriveerde, werden de gasten opgewacht door de resident, L. van Stenis, en andere Nederlands-Indische bestuursambtenaren. Voor de meeste Europese gasten was het bezoek aan Karangasem vooral een gezellig uitje. 'Gedurende drie dagen waren een 100 tal Europeanen de gast van Goesti Bagoes. De poeri (het paleis) was gedurende dien tijd de kostelooze club, waar men 's morgens, 's middags en 's avonds gezellig bijeenkwam', aldus Eland. De boot had zelfs 6.000 kilo ijs uit Surabaya meegebracht! ${ }^{7}$

Echter, 'de heer Schwartz, gewezen Assistent Resident van Bali, gaf den aanwezigen tekst en uitleg van de vele ceremonieën, noodig om de ziel van den overledene op een richtige wijze naar den hemel te voeren. ${ }^{\text {B }}{ }^{2}$ Schwartic 
was lange tijd bestuursambtenaar op Bali geweest en werd alom geprezen voor de goede contacten die hij onderhield met de inheemse vorsten, zijn gedegen kennis van de Balinese taal en cultuur en zijn bereidheid deze kennis met anderen te delen. ${ }^{9}$ Ook Bosch vermeldde later in zijn verslag van de reis hoeveel hij te danken had gehad aan de grote kennis van Schwartz. ${ }^{10}$

\section{De functie van de rituele doeken}

De uitleg van Schwartz werd door Eland benut bij zijn beschrijving van het ritueel en de hierbij gebruikte attributen en versieringen. Nadat Gusti Djelantik was overleden, werd zijn lichaam gewassen en daarna gebalsemd en gewikkeld in een groot aantal witte doeken en in statie op een verhoogde baleh baleh neergelegd. Het geheel werd overdekt door een boogvormigen bamboe krat, daaroverheen een 15 tal doeken en ten laatste gedekt door een witten, met gouden figuren versierden doek, kain prada geheeten. [...] Het lijk van den overleden vorst lag onder een voor deze gelegenheid gebouwde baldakijn. Twee smalle deuren in de omheining gaven toegang tot de doodentent [...] Langs den bovenrand van de lijkenkamer waren lange doeken gespannen, waarop voorstellingen uit den Atharwa (bedoeld wordt: Adiparwa, FB) waren aangebracht.' ${ }^{11}$ De foto's van Leydie Melville en andere fotografen bevestigen deze beschrijving. ${ }^{12}$ De met schilderingen versierde 'doodentent' was een tijdelijke uitbreiding van een gedeelte van het paleis dat 'Amsterdam' werd genoemd. Op OD-foto 2633 is de kain prada te zien die fungeerde ter decoratie van het gewelf van bamboe waaronder het lichaam van de vorst lag (afb. 1). ${ }^{13}$

Waar het doek dat later eigendom was van resident Van Stenis tijdens de crematie is gebruikt, is op grond van de foto's en verslagen niet precies vast te stellen. Het is goed mogelijk dat het doek is gebruikt in een ander (tijdelijk) paleisgebouw, aangezien schilderingen op doek op Bali van oudsher gebruikt worden als versiering van paleizen en van ruimtes waar rituelen plaatsvinden. ${ }^{14}$

\section{Afbeelding 1}

Het gewelf waaronder het lichaam van I Gusti Gde Djelantik lag, bedekt met de kain prada. Foto Oudheidkundige Dienst (OD) foto 2633 , courtesy Vrienden van de Vereniging Instituut Kern

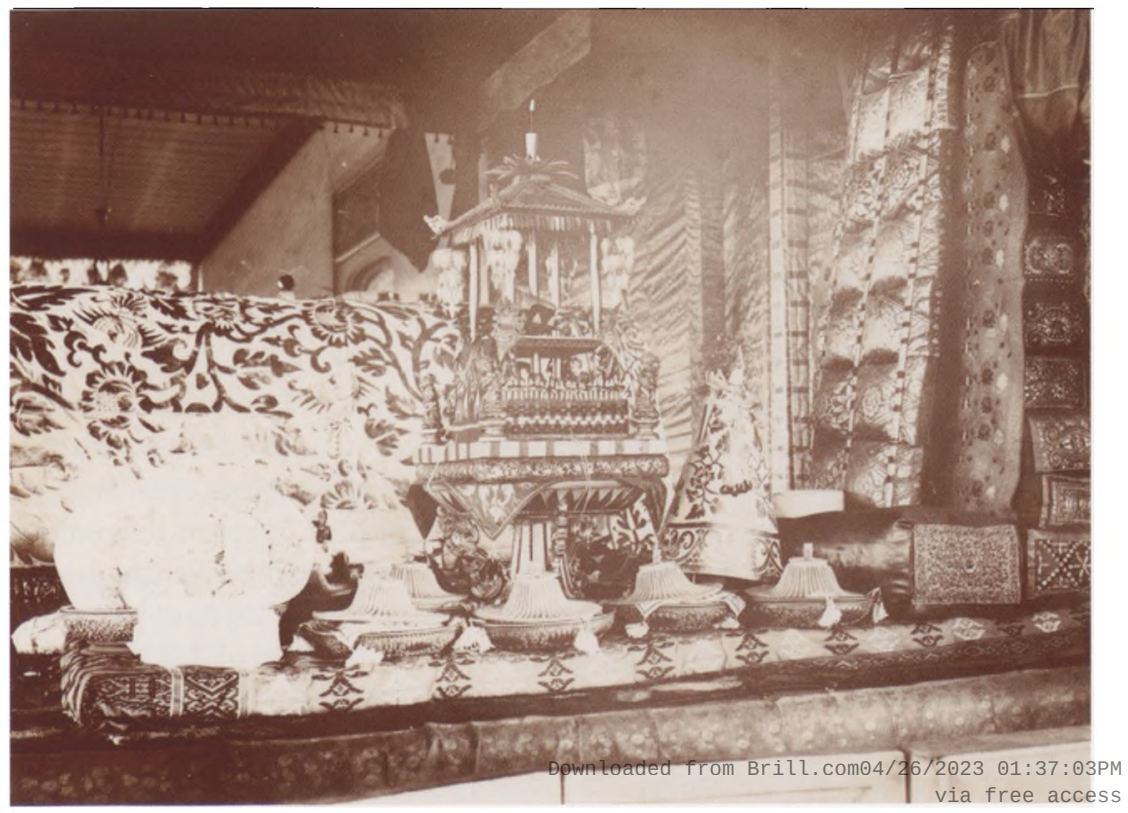


Deze schilderingen kunnen allerlei afmetingen hebben, maar juist uit het paleis van Karangasem zijn meer voorbeelden bekend van hele grote schilderingen als rituele decoraties. Zo schrijft de schilder W.O.J. Nieuwenkamp, in 1932 te gast bij het huwelijk van Gusti Bagus Djelantik: 'Er was een enorme feesthal opgericht, versierd met bloemen en mooie Balische schilderingen op enorme lappen wit katoen. ${ }^{15} \mathrm{En}$ bij de grote maligia (een zuiveringsceremonie voor de ziel) voor Gusti Bagus Djelantik, werden schilderingen van zeer grote afmetingen gebruikt, van de hand van de bekende Balische schilder I Gusti Ketut Kobot. ${ }^{16}$

Het hof van Karangasem had, voor zover bekend, geen eigen schildertraditie. Waarschijnlijk zijn de doeken voor de crematie in 1916 op bestelling gemaakt door schilders uit het dorp Kamasan, die vroeger in dienst waren van de Dewa Agung van Klungkung. ${ }^{17}$ De kain prada, de met figuren van bladgoud versierde doek, is vermoedelijk in Karangasem zelf gemaakt.

\section{Verzamelen na afloop van de crematie}

De meest spectaculaire attributen voor het ritueel, bestaande uit een metershoge, prachtig versierde toren waarin het lijk naar de crematieplaats werd gebracht, sarcofagen voor de vorst en zijn vrouw in de vorm van een stier en een leeuw, en een grote slang die de ziel van de vorst symbolisch vervoerde, werden tijdens de crematie verbrand. Vele decoraties van de ruimtes in het paleis die speciaal waren ingericht voor het ritueel, waaronder de schilderingen, moeten na afloop echter nog aanwezig zijn geweest, en zouden vermoedelijk niet opnieuw gebruikt gaan worden.

Waarschijnlijk heeft Van Stenis, resident van Bali en Lombok van 1914 tot 1919, zijn beschilderde doek toen van Gusti Bagus Djelantik ontvangen, uit hoofde van zijn functie. Het was niet ongebruikelijk dat Balinese schilderingen door vorsten ten geschenke werden gegeven aan het Nederlands bestuur. ${ }^{18}$

De vroegere eigenaar van de andere schildering, H.T. Damsté, was de opvolger van Van Stenis. Van 1919 tot 1923 was hij resident, en na zijn overlijden werd hij door V.E. Korn geprezen als 'een der grootste figuren waarop het B.B.-corps heeft kunnen bogen. In zijn vierjarige residentperiode slaagde Damsté erin zich te ontplooien tot een gewestelijk bestuurder als Bali en Lombok na Liefrinck niet had gekend en niet meer zou kennen.'19 Damsté was ook verzamelaar van voorwerpen die vooral met Balinese schilderkunst en dodenritueel te maken hebben, waarover hij ook publiceerde. In die zin sluit deze aanwinst voor Volkenkunde goed aan bij collecties die eerder van Damsté zijn ontvangen. ${ }^{20}$ In 1916 was Damsté echter, volgens Korn, in Nederland en hij kan zijn doek dus niet na afloop van de crematie hebben verzameld. Misschien heeft hij de schildering gekregen van zijn voorganger bij zijn aantreden als resident, of later in Karangasem ontvangen van Gusti Bagus Djelantik zelf.

Schwartz, met de specifieke opdracht om te verzamelen voor het museum in Batavia, slaagde erin om na het ritueel twee prachtige doeken te bemachtigen, die hij als volgt beschreef: 'Voorhangsel van wit katoen, waarop in kleuren geschilderd en verguld een voorstelling van de redding van Soegriwa door zijn neef Anoman uit de handen van Koembhakarna. Het doek heeft deel uitgemaakt van de bekleeding van de bale pawédajan (tribune), waarin pedanda's dagelijks godsdienstoefeningen hielden voor de verbranding van het lijk van Goesti Gde Djlantik, oud stedehouder van Karangasem, 
Afbeelding 2

Detail van schildering op doek, De strijd met Kumbakarna,

h. $173,5 \mathrm{~cm}$., I. $221 \mathrm{~cm}$., Bali, Nationaal Museum, Jakarta, inv.nr. 17626.

Foto F. Brinkgreve

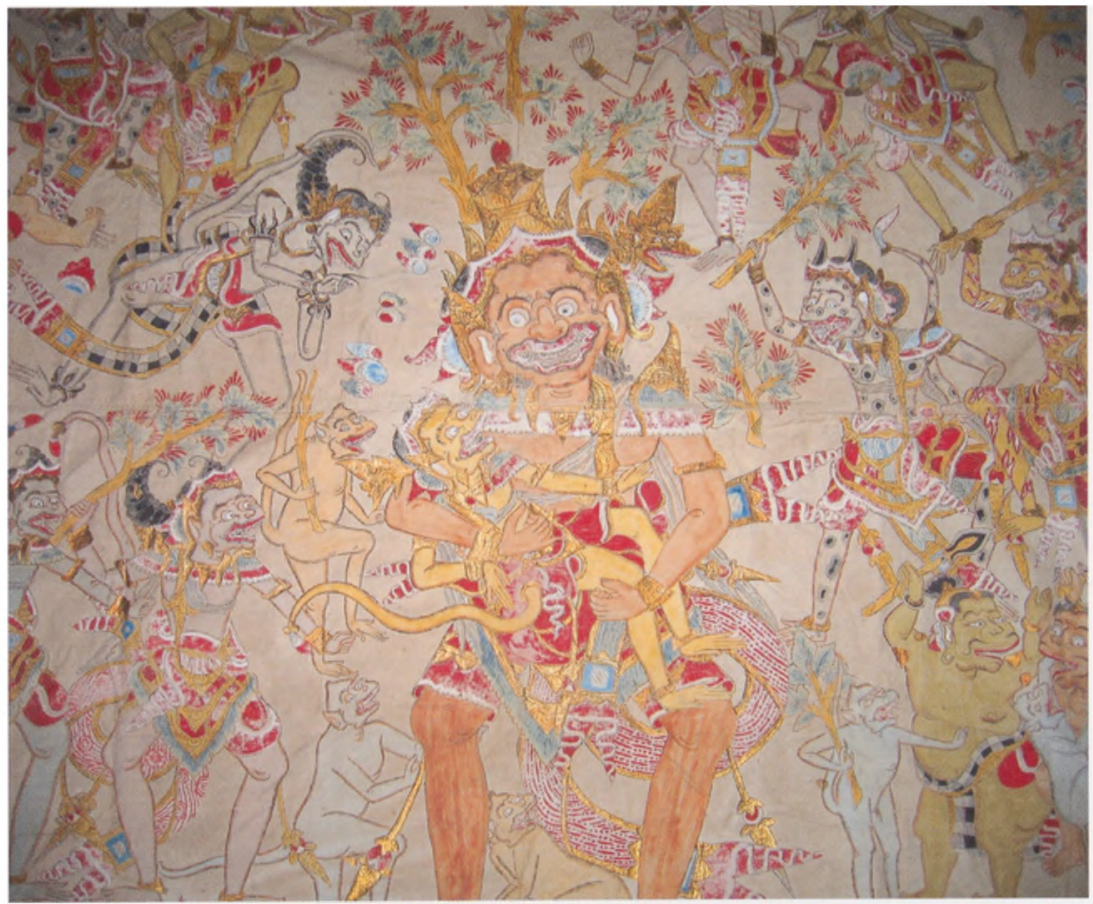

\section{Afbeelding 3}

Detail van de kain prada, br. $273 \mathrm{X}$

I. $455 \mathrm{~cm}$., Bali, Nationaal Museum, Jakarta, inv. nr. 17852. Foto F. Brinkgreve

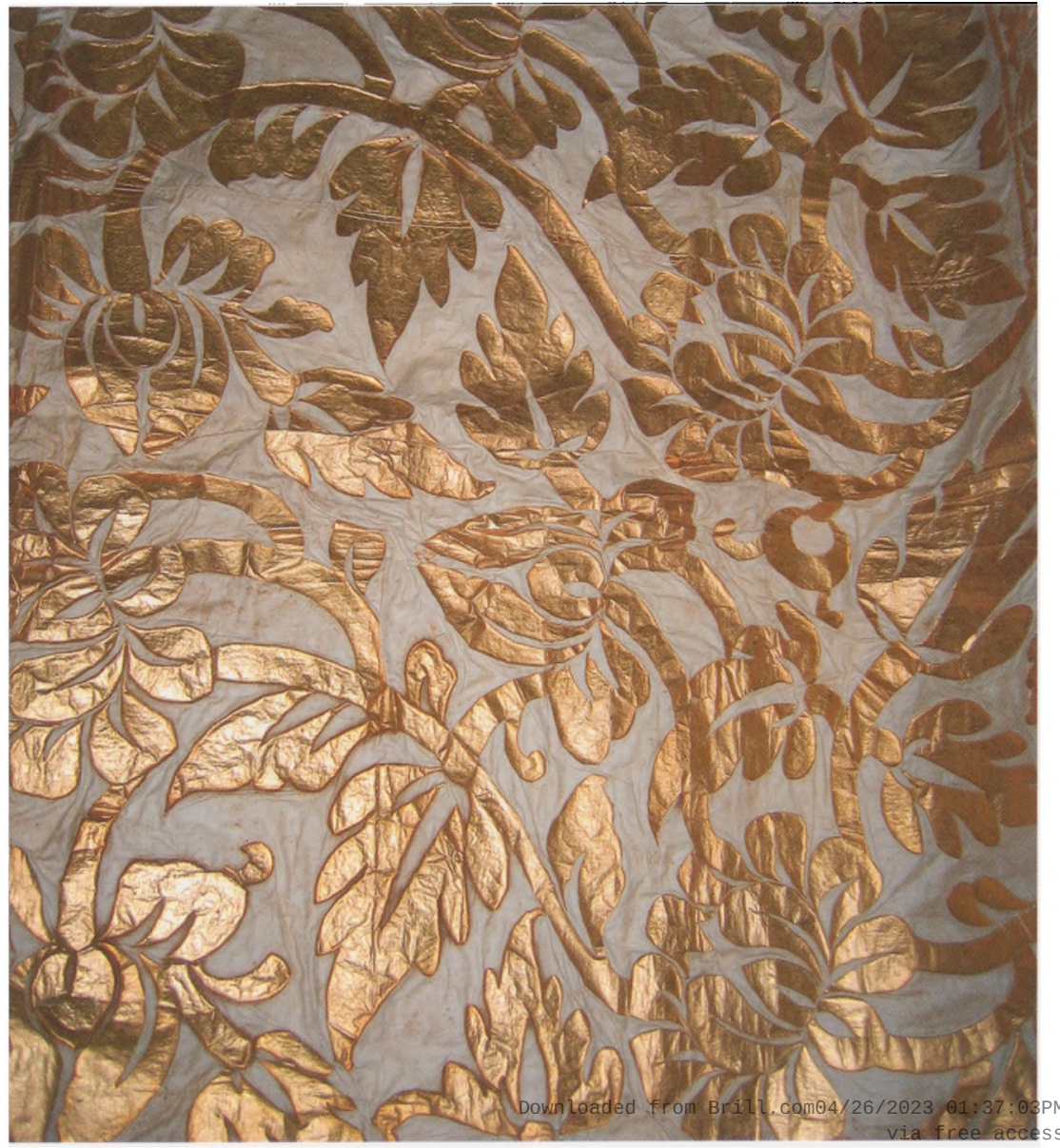




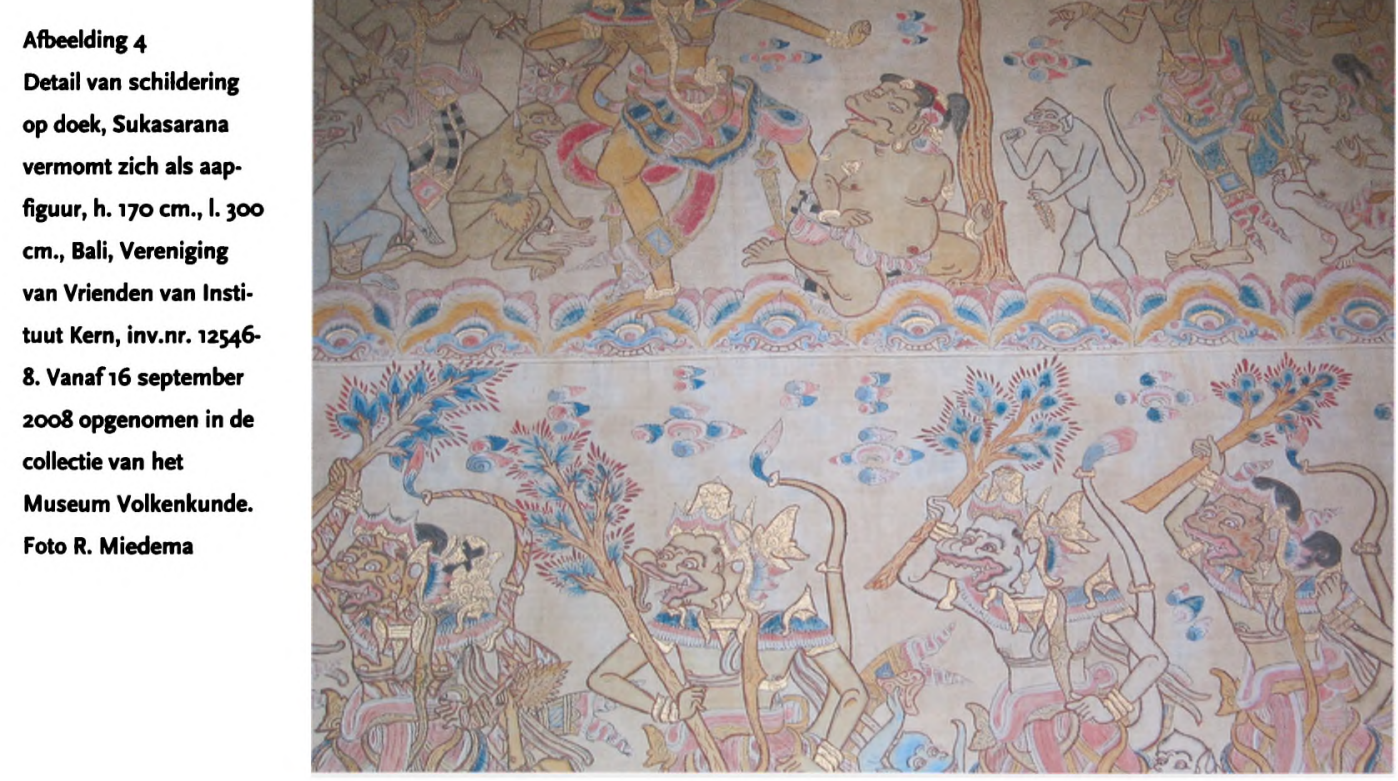

De schildering, een geschenk van Gusti Bagus Djelantik, werd speciaal getoond in de bestuursvergadering van het Batviaasch Genootschap nadat Bosch en Schwartz waren teruggekeerd (afb. 2). Helaas is de schildering op de foto's van de crematie niet zichtbaar.'22

De andere doek die Schwartz verzamelde, was het 'lijkkleed (kereban) van wit katoen met sierlijke gouden bloem- en bladfiguren beplakt [...]. Hiermede was de saloe pinda, zoals rustbank en gewelf te zamen ook genoemd worden, met daarover heen liggende 107 witte lakens geheel bedekt. ${ }^{23}$ Schwartz had dus niet alleen de kain prada die Eland had beschreven verzameld (afb. 3), maar ook de laatste rustplaats van de overleden vorst zelf. Bovendien liet hij een aantal modellen maken van offeraltaren die functioneerden bij deze crematie. ${ }^{24}$ De reis van Schwartz was in andere opzichten eveneens succesvol, want hij verzamelde, inclusief achtergrondinformatie, vele voorwerpen die tegenwoordig, na bijna 100 jaar, nog steeds een belangrijk deel uitmaken van de exposities in het Nationaal Museum in Jakarta.

\section{Schilderingen met Ramayana-voorstellingen}

De schilderingen die na afloop van de crematie zijn verzameld door Van Stenis en Schwartz, zijn afbeeldingen uit het Ramayana epos, het van oorsprong Indiase epos over de mythische prins Rama wiens geliefde Sita wordt ontvoerd door de demonenkoning.

Het doek dat mevrouw Van Stenis-James schonk aan de Vereniging van Vrienden van Instituut Kern en waarvan helaas nog geen overzichtsfoto beschikbaar is, heeft een afmeting van $170 \times 300 \mathrm{~cm}$. (afb. 4). Voor de schilderingen zijn de kleuren lichtrood, donkerrood, okergeel, donkerbruin, lichtblauw, donkerblauw, wit, grijs, zwart en goud gebruikt. Het doek bestaat uit twee scènes, die worden gescheiden door een rotsmotief. In de scène $e_{\text {ee }}$ access 
boven zijn links van de boom vijf dierlijke figuren met een staart te zien. Dit zijn aapfiguren, die deel uitmaken van het apenleger. Omdat ze van hogere rang zijn dan gewone apen, hebben ze een menselijk bovenlichaam en dragen ze hoofdtooien, sieraden en kleding. Wel hebben ze het gezicht van een dier, een dierlijke vacht en grote poten. Elke aapfiguur is een individu, met een eigen naam en te identificeren aan zijn hoofdtooi, gezichtskenmerk of vacht. ${ }^{25}$ Toch fungeren de aapfiguren op traditionele schilderingen voornamelijk als groep en hoeven ze niet allemaal geïdentificeerd te worden om het afgebeelde verhaal te kunnen begrijpen. Een aapfiguur die in het Ramayana een belangrijke rol speelt en op de doeken vaak een hoofdrol heeft, is Hanuman, de apengeneraal. Hij is te herkennen aan zijn witte vacht, zijn hoofdtooi, de gelung buana lukar, zijn puntige armbanden en de zwartwit geblokte sjerp. ${ }^{26} \mathrm{Op}$ dit doek is hij de vierde aapfiguur van links. Verder zijn aan de linkerkant van de boom nog vier gewone apen te zien en een dienaar, genaamd Twalen. ${ }^{27}$

Aan de andere kant van de boom, in het midden, staat Rama. Rama spreekt; dit is te zien aan zijn handhouding. Hij draagt een kroon met hiervoor een diadeem en aan de achterkant is zijn hoofdtooi versierd met een garuda mungkur, een vogel-ornament dat als bescherming dient tegen het kwaad dat van achter komt. Rechts naast Rama staat zijn broer Laksmana, te herkennen aan zijn hoofdtooi, de gelung supit urang ('kreeftenklauw') met garuda mungkur. Achter Laksmana staat Wibisana, de broer van demonenkoning Rawana. ${ }^{28} \mathrm{Hij}$ heeft zijn hand ook in de houding van spreken. Achter Wibisana staat apenkoning Sugriwa. Wibisana en Sugriwa zijn te identificeren aan hun hoofdtooien. ${ }^{29}$

De aapfiguur rechts naast Hanuman lijkt op het eerste gezicht dezelfde hoofdtooi te dragen als Sugriwa. Maar bij nadere bestudering is te zien dat deze figuur geen hoofddoek draagt, maar zijn lange haar los draagt: het is Sukasarana, een demon die als spion door Rawana naar het kamp van Rama gestuurd wordt, om te inventariseren hoe groot het apenleger is dat Rama helpt en wat de zwakte van het leger is. Hij vermomt zich daarom als aap om dichterbij te kunnen komen. Hij wordt herkend door Wibisana die vervolgens Rama informeert en hem vraagt om de demon in vermomming te doden. ${ }^{30}$ De bovenste scène van dit doek beeldt deze episode uit: de ontmaskering van Sukasarana. ${ }^{31}$

In de scène die de hele onderkant van het doek beslaat, zijn acht aapfiguren te zien en zeven gewone apen. De aapfiguren zijn gewapend met takken of hele bomen. Ook de gewone apen dragen wapens: kleine takken en stenen. Aannemelijk is dat deze scène voorafgaat aan de bovenste scène, omdat Sukasarana (uiterst links op het doek) hier nog in vermomming deel uitmaakt van het apenleger (afb. 5). Opmerkelijk is de tweede gewone aap van rechts, vanwege zijn andere vacht. Dit is niet gebruikelijk, omdat de apen in tegenstelling tot de aapfiguren geen eigen naam en gezichtskenmerk hebben of te identificeren zijn aan een hoofdtooi. De kunstenaar heeft deze aap waarschijnlijk een andere vacht gegeven om te benadrukken dat dit doek verhaalt over een vermomming.

De schildering die Schwartz verzamelde voor het museum in Batavia (het huidige Nationaal Museum in Jakarta) heeft een afmeting van 173,5 221 $\mathrm{cm}$. Het doek beeldt het gevecht uit tussen het apenleger en Kumbakarna, een broer van demonenkoning Rawana (zie afb. 2), , De apen proberen hem $^{\circ}$, 
Afbeelding 5

Detail: Sukasarana

vermomd als aapfiguur.

Foto R. Miedema

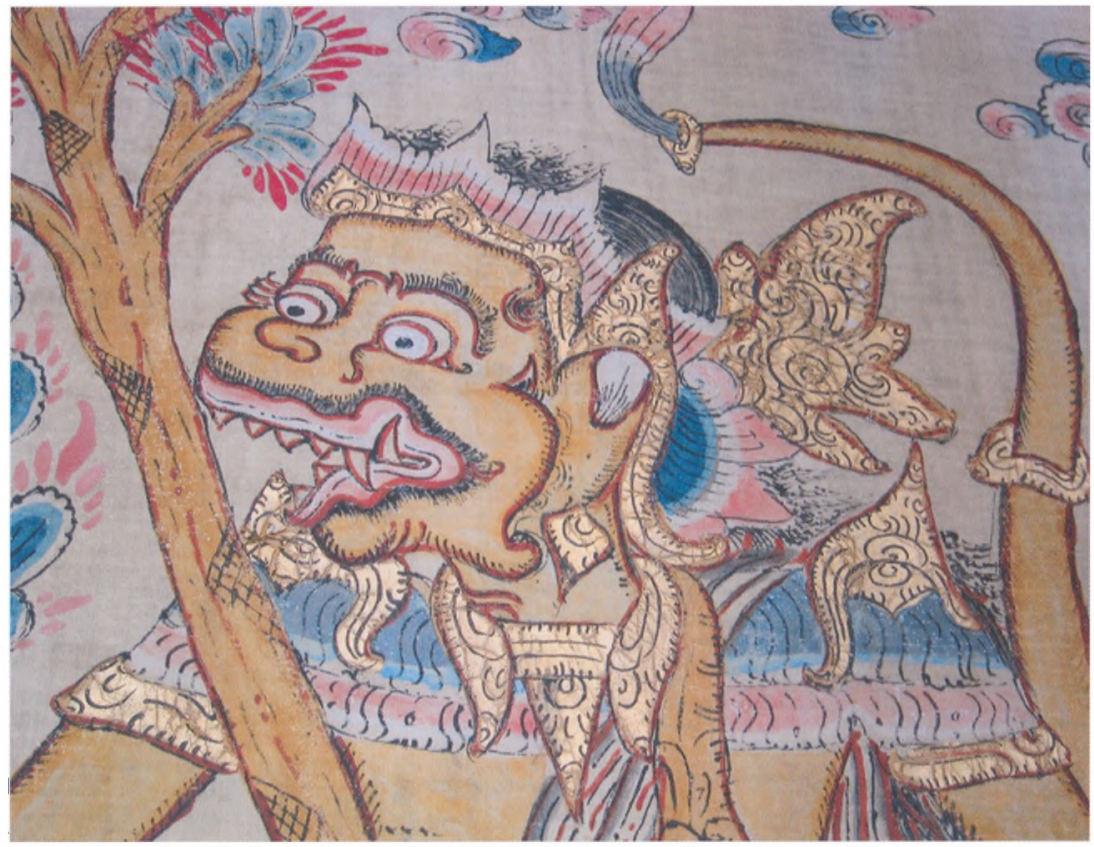

met stenen en takken te doden, maar dat lukt niet. Hij pakt ze bij bosjes op en verslindt ze. ${ }^{33}$ Vervolgens zal apenkoning Sugriwa met hulp van generaal Hanuman tegen hem strijden, maar Sugriwa wordt door Kumbakarna gegrepen. ${ }^{34}$ Dit is te zien op het doek: in het midden zien we Kumbakarna met zijn woeste uiterlijk, gekenmerkt door de grote ogen en de zeer grote mond. In de traditionele Balinese schilderingen wordt hij vaak en face afgebeeld, in tegenstelling tot de andere figuren die deels en trois quarts, deels en profile worden afgebeeld. ${ }^{35}$ In zijn armen houdt hij Sugriwa in een greep. Kumbakarna wordt omringd door verschillende gewapende aapfiguren, onder andere Hanuman, met zijn zwart-wit geblokte sjerp, en een aantal gewone apen. $\mathrm{Zij}$ proberen hun koning te bevrijden en de vijand te verslaan. Rechtsonder worden de dienaren Delem en Sangut aangevallen door twee apen. Uiteindelijk weet Sugriwa zichzelf los te maken uit de armen van Kumbakarna door diens neus af te bijten en een van zijn oren van zijn hoofd te trekken. Laksmana en Rama doden hem vervolgens met hun pijlen. ${ }^{36}$

\section{De strijd om onsterfelijkheid}

Het doek geschonken door Damsté, geeft de strijd om het onsterfelijkheidelixer (de amrta) weer, een episode uit de Adiparwa, het eerste boek van het van oorsprong Indiase epos Mahabharta (afb. 6). ${ }^{37}$ Deze Balinese schildering heeft een afmeting van $166 \mathrm{bij} 455 \mathrm{~cm}$. en bestaat uit drie scènes. De gebruikte kleuren zijn lichtrood, donkerrood, okergeel, bruin, lichtblauw, donkerblauw, wit, grijs, zwart en goud. De scènes zijn gescheiden door middel van rotsmotieven.

Om de amrta te kunnen bemachtigen, die in een kruik op de bodem van de oceaan ligt, moeten de goden en demonen samen de melkoceaan karnen. ${ }^{38}$ De berg Mandara wordt met behulp van de slang Ananta uit de aarde getrokken om als karnstok te dienen. Schildpadkoning Akupa, een incarnatie van Vishnu, draagt Mandara op zijn rug opdat de berg niet zal zinken in de 


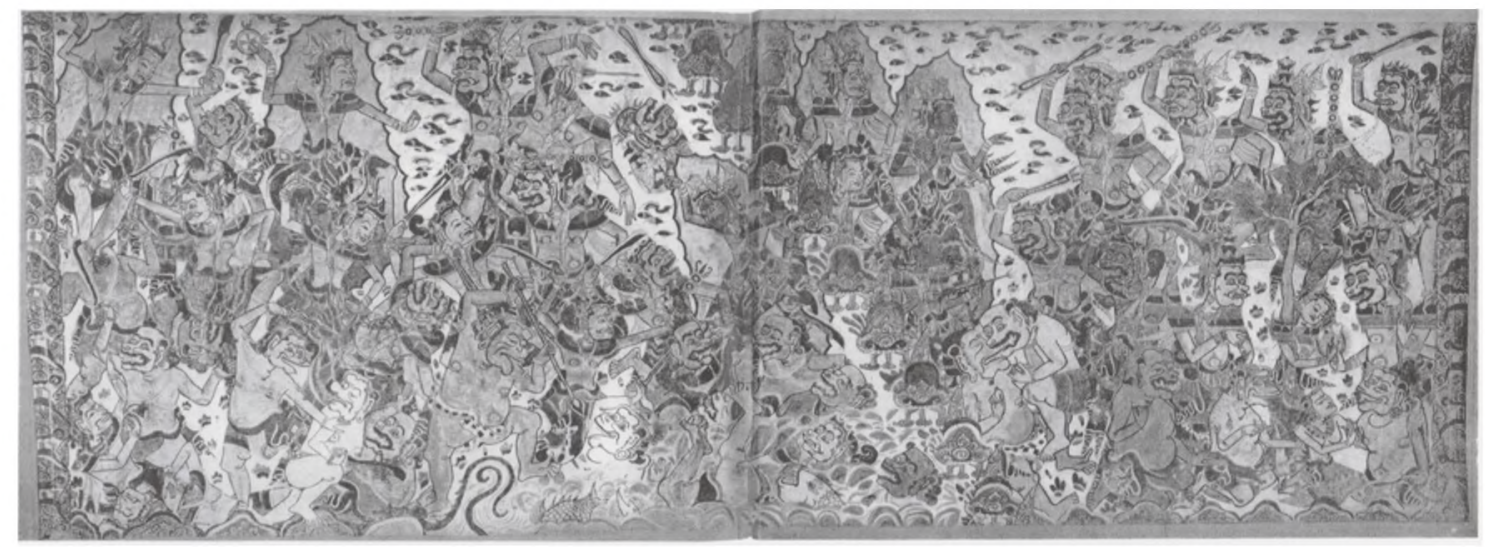

\section{Afbeelding 6}

Schildering op doek, Strijd tussen de goden en demonen om de amrta, h. $166 \mathrm{~cm}$., I. $455 \mathrm{~cm}$., Bali, Vereniging van Vrienden van Instituut Kern, inv.nr. 12546-7. Vanaf 16 september 2008 opgenomen in de collectie van het Museum Volkenkunde. Uit Goedheer 1939 (zie noot 37) oceaan. De slang Basuki, gewikkeld om Mandara, dient als karntouw: de goden trekken aan de staart, de demonen aan de kop. Het karnen is succesvol: uit het water komen onder andere de godinnen Sri en Laksmi omhoog, als ook de witte olifant Airawata en het witte paard Ucaisrawa. Als laatste komt de god Dhanwantari te voorschijn, die de amrta bij zich draagt. Maar de demonen weten het elixer direct in bezit te krijgen. De god Vishnu besluit daarom zich te vermommen als een prachtige vrouw om de demonen te verleiden en de nectar van hen af te pakken. Het plan slaagt; nog voor de demonen van de onsterfelijkheidsdrank hebben kunnen drinken, zijn ze die alweer kwijt.

Dit is de eerste scène, die zich rechtsonder op het doek afspeelt: we zien Vishnu in de gedaante van een vrouw met twee demonen links en rechts van haar. Middels de boom achter Vishnu in vermomming, is te zien dat er een conversatie plaatsvindt. ${ }^{39}$ De demon aan haar linkerkant geeft haar een kelk met de amrta. Onder haar zien we Delem en Sangut, de twee dienaren van de demonen, ook met een vrouw. Delem is de grootste van de twee, vooral herkenbaar aan de bult onder zijn kin. Sangut, de kleinere, heeft herkenbare uitpuilende lippen. De vrouw drukt haar rechterhand tegen de rechterhand van Delem.

Vishnu, inmiddels weer in zijn eigen gedaante, snelt terug naar de andere goden, achterna gezeten door de demonen. De andere goden schieten Vishnu te hulp en er breekt een oorlog uit tussen de goden en demonen. De tweede scène is rechtsboven op het doek afgebeeld. Vier demonen heffen hun wapens tegen drie goden, te herkennen aan de aureolen. De rechter god, Vishnu, draagt een kroon met aan de achterkant een garuda mungkur; in zijn rechterarm houdt hij de kelk met de amrta. Shiva, in het midden, draagt ook een kroon met een garuda mungkur aan de achterkant. Boven zijn ogen is zijn derde oog zichtbaar. De derde god is niet helemaal te zien. Hij draagt een hoog hoofddeksel met aan de voorkant een kroon en aan de achterkant een garuda mungkur. Dit zou Brahma kunnen zijn.

De twee hiervoor genoemde scènes worden gescheiden van de rest van het doek middels een rotsornament, dat schuin over het doek loopt. Aan de $\mathbf{e}_{\text {ree access }}$ 


\section{Afbeelding 7}

Voorzijde vaste poeriverblijf 'Amsterdam' met tijdelijke uitbreiding (links). OD foto 2634, courtesy Vrienden van de Vereniging Instituut Kern

\section{Afbeelding 8}

Voorzijde vaste poeriverblijf 'Amsterdam' met tijdelijke uitbreiding (midden). OD foto 2635 , courtesy Vrienden van de Vereniging Instituut Kern

\section{Afbeelding 9}

Voorzijde vaste poeriverblijf 'Amsterdam' met tijdelijke uitbreiding (rechts). OD foto 2636 , courtesy Vrienden van de Vereniging Instituut Kern
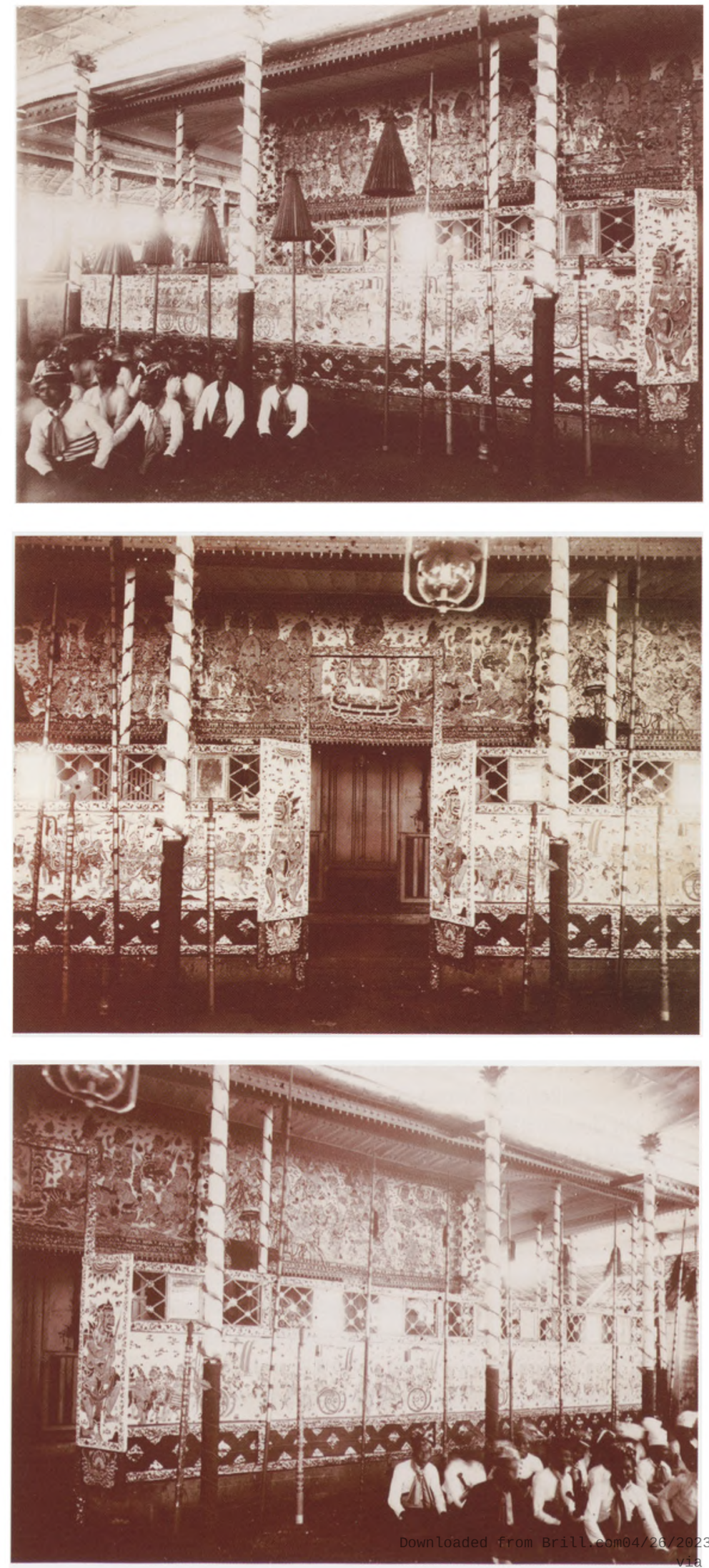
linkerkant van dit rotsornament zijn verschillende gevechten te zien. Op Balinese schilderingen heeft iedere figuur één tegenstander in een gevecht en het vechtende koppel is altijd op zo'n manier afgebeeld dat de twee vijanden elkaar aankijken. Het is daarom in een gevechtsscène altijd duidelijk te zien wie tegen wie vecht. Figuren van gelijkwaardige stand vechten tegen elkaar. Figuren van een lage afkomst worstelen met elkaar en raken elkaar aan. Goden en koningen bevechten de vijand echter van een afstand met wapens die die afstand kunnen overbruggen, zoals een cakra (discusrad), en pijl en boog. ${ }^{40}$

Onderin is bijvoorbeeld te zien dat de dienaar Twalen de demonendienaar Delem ombrengt met een speer. Delem ligt al op de grond, in het water. Links van dit tafereel wordt Merdah van achter aangevallen door Sangut, die een kris in zijn hand heeft. Merdah heeft net een andere demonische dienaar aangevallen met een zwaard. In de hoek linksonder zien we een demonische figuur met geheven zwaard. Een krijger, die al gevallen is, heeft hem bij zijn rechter bovenarm vastgepakt en steekt hem in zijn buik met een kris. Op de grond ligt nu dezelfde krijger: het is de demon toch nog gelukt hem te onthoofden.

Boven deze taferelen zien we rechts een demon die bij zijn haren gegrepen wordt, en Shiva die dreigend boven een demon hangt. Links is een demon te zien met een cakra in zijn borst. Tot slot is rechtsboven op het doek Vishnu te zien in gevecht met een demonenkoning. In zijn rechterhand houdt hij zijn discusrad. De demon, twee keer afgebeeld, wordt door de cakra onthoofd. De goden winnen uiteindelijk de oorlog van de demonen, keren terug naar Wisnuloka, drinken de amrta en worden daarmee onsterfelijk.

\section{De bevrijding van de ziel}

Terug naar het crematieritueel van I Gusti Gde Djelantik. Het hiervoor beschreven doek dat de strijd om de onsterfelijkheidsdrank vertelt, is duidelijk terug te zien op foto's die gemaakt zijn van de crematieplechtigheid. Op de OD foto's 2634-2636 zien we de voorkant van de uitbreiding van het gebouw 'Amsterdam' in het paleis van Karangasem, waar het lichaam van Djelantik was geborgen (afb. 7-9). De dakrand is versierd met drie Balinese schilderingen, die zijn verrijkt met kwastjes aan de onderkant. Het is het rechter doek dat de Vereniging van Vrienden van Instituut Kern onlangs heeft geschonken aan Museum Volkenkunde in Leiden.

Uit de foto's is te herleiden dat het doek van Damsté deel uitmaakt van een serie doeken, die verhalen over het verkrijgen van onsterfelijkheid. Op de twee doeken die links van het doek van Damsté hangen, zijn de voorafgaande episodes aan de strijd om de onsterfelijkheidsdrank (de bijeenkomst van de goden en het karnen van de oceaan) zichtbaar. Op Bali worden ceremoniële gebouwen vaak niet alleen aan de voorkant, maar rondom versierd met doeken, ider-ider genaamd (ider betekent 'rondom'). ${ }^{41}$ Als het doek van Damsté een gedeelte is van een ider-ider en de bale voor I Gusti Gde Djelantik ook aan de zijkanten was versierd met doeken, zou dit betekenen dat er nog meer doeken zijn geweest. Hoogstwaarschijnlijk verbeeldden de doeken aan de linker zijkant dan de episodes die zich voor de bijeenkomst van de goden afspelen en aan de rechterkant was wellicht te zien hoe demon Rahu ook een druppel van de onsterfelijkheidsdrank weet te bemachtigen. ${ }^{42}$ 


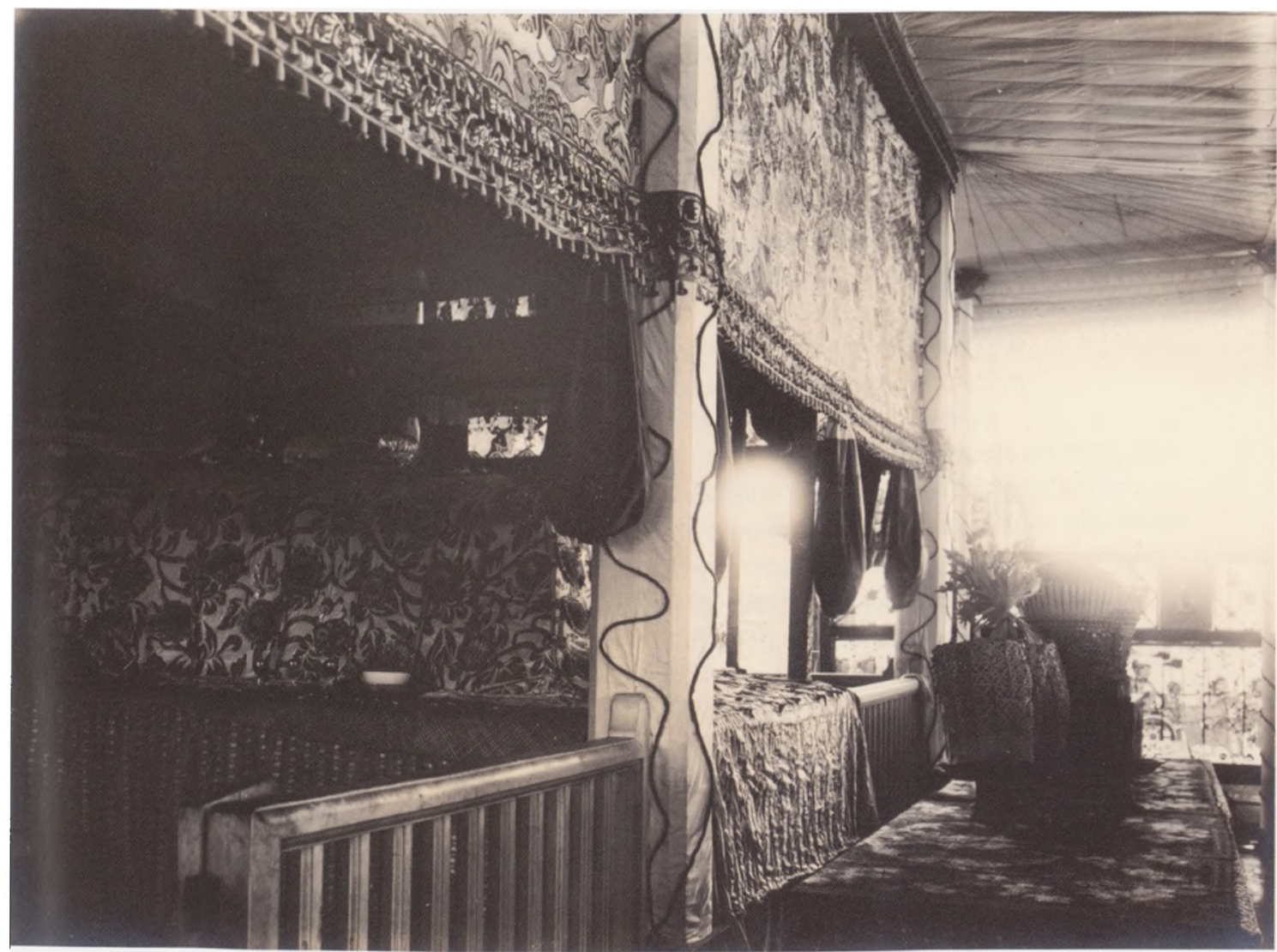

Afbeelding 10

Detail van de tijdelijke uitbreiding van paleisgebouw 'Amsterdam', waar het lichaam van Djelantik was geborgen. OD foto 2630 , courtesy Vrienden van de Vereniging Instituut Kern
Op afbeelding 10 is te zien dat het lichaam van I Gusti Gde Djelantik lag aan de rechterkant van de 'doodentent', met erboven, aan de dakrand, de doeken van OD foto's 2635 en $2636 .{ }^{43}$ Hieruit blijkt nog eens extra hoe bijzonder het doek geschonken door Damsté is: dit doek versierde de bale precies op de plek waar de dode vorst lag. Dit is geen toeval, want juist door het crematieritueel zou de bevrijding van de ziel plaatsvinden. Het verhaal op het doek bevestigt dus het doel van het ritueel.

\section{Noten}

1. Met dank aan: Ellen Raven, Gerda Theuns, Haryanti (Museum Nasional, Jakarta), Pieter ter Keurs, David Stuart-Fox en Pauline Lunsingh Scheurleer zelf voor hulp bij het onderzoek en commentaar op eerdere versies van dit artikel.

2. Jaarverslag 1930-1933 Instituut Kern, Leiden, 1934, p. 4.

3. Ter gelegenheid van deze ambtsoverdracht werd in Karangasem een groots offerfeest georganiseerd, waarbij prachtige geschenken werden aangeboden aan Koningin Wilhelmina en gouverneur-generaal Van Heutsz, die nu deel uitmaken van museale collecties. Zie F. Brinkgreve, 'Vorsten van Bali en koloniaal gezag, collectievorming en politiek', in Endang Sri Hardiati \& Pieter ter Keurs (red.), Indonesia; de ontdekking van het verleden, Amsterdam, 2005, pp. 124-126.

4. L. Eland, 'Naar Bali', De Reflector, geillustreerd weekblad voor Nederl.-Indië, 1/44, Batavia (21 oktober 1916), pp. 1111-1121 en 45 (28 oktober 1916), pp. 1139-1142. Zie ook: H. Marchand, 'De lijkverbranding op Bali' en 'De lijkverbranding te Karan-: gasem', Weekblad voor Indië, 13/27 (15 oktober 1916), pp. 633-635 en 655i-656ee access 
5. Notulen van de directievergaderingen van het Bataviaasch Genootschap van Kunsten en Wetenschappen, 3 juli 1916, pp. 96-97. Zie ook: Notulen, 13 oktober 1916, p. 141.

6. Zie bijvoorbeeld de beschrijving van de lijkverbranding van Tjokorda Gde Agung Sukawati op 31 januari 1979 in Ubud, in: F. Brinkgreve, 'Een crematie-ceremonie op Bali', Verre Naasten Naderbij, 13/2 (1979), pp. 51-64. Van deze crematie zijn ook verschillende films gemaakt, o.a. Bali verbrandt een vorst, door de NOS. Een recenter voorbeeld is: L. Lueras, Fire, a Balinese journey of the soul, Gianyar, 1994.

7. L. Eland, Op.cit. (noot 4), p. 1117.

8. L. Eland, Op.cit. (noot 4), p. 1119.

9. Zie F. Brinkgreve and D. Stuart-Fox, 'Collections after Colonial Conflict, Badung and Tabanan 1906-2006', in P. ter Keurs (red.), Colonial Collections Revisited, Leiden, 2007, pp. 145-186.

10. F.D.K Bosch, 'Bali', Oudheidkundig Verslag over het Vierde kwartaal 1916,

Weltevreden/'s-Gravenhage, 1917, p. 107.

11. L. Eland, Op.cit. (noot 4), pp. 1119-1121.

12. In het artikel van Eland zijn ook foto's van de crematie opgenomen, gemaakt door Hisgen, uit Semarang. Ook het Museum Volkenkunde bezit een aantal foto's van de crematie, gemaakt door Tjokorda Gde Raka Sukawati uit Ubud, Bali. De nummers zijn: 556Fa12a en b; 556Fa20a en b.

13. F.D.K. Bosch, 'Bijlage Q Lijst der fotografische opnamen in het 4de kwartaal 1916', Oudheidkundig Verslag 1916, p. 121.

14. A. Forge, Balinese traditional paintings, Sydney, 1978, p. 6.

15. W.O.J. Nieuwenkamp, 'Op Bali terug', Elseviers geillustreerd maandblad LXIV (1932), p. 11.

16. Deze doeken sierden sindsdien de wanden van de woonkamer van Dr. A.A. Made Djelantik, een zoon van Gusti Bagus. Hij vertelde de schilderingen na afloop van het ritueel te hebben meegenomen omdat ze in het paleis ongebruikt zouden blijven.

17. A.A. Made Djelantik, Balinese Paintings, Singapore, 1986, p. 17: ‘On many occasions, other kings of Bali, such as those of Karangasem, asked the Dewa Agung for painters from Karangasem to work at their courts.'

18. A. Forge, Op.cit. (noot 14), p. 6.

19. V.E. Korn, 'In memoriam Henri Titus Damsté 28 jan 1874 - 6 jan 1955', Bijdragen tot de Taal-, Land- en Volkenkunde III (1955), p. 114. F.A. Liefrinck was resident van Bali en Lombok en vervolgens Raad van Indië (adviseur van de gouverneurgeneraal). Hij was ook voorzitter van het Bataviaasch Genootschap.

20. O.a.: H.T. Damsté, 'Balische kleedjes en doeken, verband houdende met eeredienst en doodenzorg', Koninklijk Instituut voor de Taal- Land en Volkenkunde van Nederlandsch-Indië, 's Gravenhage; gedenkschrift uitgegeven ter gelegenheid van het 75-jarig bestaan op 4 juni 1926, 's Gravenhage,1926, pp. 254-264. In Museum Volkenkunde zijn o.a. de series 2410 en 2524 door Damsté verzameld.

21. Notulen (zie noot 5) 1916, Bijlage VIII: Aanwinsten van de ethnografische verzameling in 1916, p. 167-168; H.J.E.F. Schwartz, Gids voor den bezoeker van de ethnografische verzameling, zaal B Bali en Lombok, Batavia, 1920, p. 19.

22. Notulen (zie noot 5), 6 november 1916, p. 149. Op de foto's van Leydie Melville (nrs. 2637-2641) zijn alleen witte doeken zichtbaar in de ruimte waar de priesters officieerden.

23. Notulen (zie noot 5), 1917, p. 186; Schwartz, Op.cit. (noot 21), p. 22.

24. MNI inv. nrs. 17827, 17828, 17830, in: Notulen (zie noot 5), 1917, p. 184-186; Schwartz, Op.cit. (noot 21), pp. 20-22.

25. R. Miedema, Ramayana op de traditionele Balinese schilderingen in Kamasan-stijl 18 doeken uit de Resink-collectie nader bekeken (doctoraalscriptie voor đé opleiding 
Talen en Culturen van Zuidoost-Azië en Oceanië, Universiteit Leiden) Leiden, 2004, pp. 43-44.

26. Miedema, Op.cit. (noot 25), p. 36.

27. Een uitgebreidere beschrijving van de dienaren is te vinden in Miedema, Op.cit. (noot 25), pp. 46-48.

28. Wibisana is het niet eens met de ontvoering van Sita en eist van Rawana dat hij Sita teruggeeft aan Rama, om zo een oorlog te voorkomen. Rawana stuurt zijn broer weg, die dan overloopt naar Rama. Episode XII t/m XIV van het Ramayana: S. Santoso, Ramayana Kakawin, New Delhi, 1980.

29. Voor beschrijvingen van Wibisana en Sugriwa, zie Miedema, Op.cit. (noot 25), pp. 48 en 46.

30. Episode XVIII: 2-5 van het Ramayana, Santoso, Op.cit. (noot 28 ).

31. De episode eindigt met Sukasarana die uiteindelijk gevangen wordt genomen door de apen. Rama heeft met Sukasarana te doen en geeft opdracht hem vrij te laten. Sukasarana keert daarna terug naar Lengka. Zie het Ramayana, episode XVIII: 6 t/m 11, Santoso, Op.cit. (noot 28).

32. Zang XXII-XXIII, Santoso, Op.cit. (noot 28).

33. Zang XXII: $45 \mathrm{t} / \mathrm{m}$ 52, Santoso, Op.cit. (noot 28).

34. Miedema, Op.cit., pp. 90-91.

35. J. Fischer, Th.J. Cooper, The Folk Art of Bali; the narrative tradition, Kuala Lumpur, 1998, p. 53.

36. Zang XXII: $67 \mathrm{t} / \mathrm{m} 89$ en XXIII: $1 \mathrm{t} / \mathrm{m} \mathrm{8}$, Santoso, Op.cit. (noot 28).

37. A.J. Goedheer, 'De strijd om de onsterfelijkheidsdrank op een Balisch doek', Cultureel Indië 1 (1939), pp. 344-346. De episode van het Mahabharata is besproken in o.a. Th.L. Cooper, 'Two Paintings Attributable to I Ketut Gedé', Archipel: Études Interdisciplinaires sur le monde Insulinden 65 (2003), pp. 148 - 150; Y.A. Rahayu, 'Hariwijaya in the Samudramanthana tradition', in: L. Chandra (ed.), Society and Culture of Southeast Asia - Continuities and Changes, New Delhi, 2000, pp. 191-194.

38. De episode van het karnen van de oceaan wordt besproken in de Samudramanthana.

39. Voor conventies in de Balinese schilderingen op doek, zie R. Miedema, 'Het linksrechts principe in de traditionele Balinese schilderingen op doek', Aziatische Kunst 35/1 (2005), pp. 3-13.

40. Zie Miedema, Op.cit. (noot 25), pp. 39, 57-58.

41. Forge, Op.cit. (noot 14) en Miedema, Op.cit. (noot 25), p. 21.

42. Demon Rahu vermomt zich als god en weet zo ook van de amrta te drinken. De zon en maan zien dit en informeren Vishnu, die daarop Rahu onthoofdt. Rahu die net de eerste druppel doorslikt verliest zijn lichaam, maar zijn hoofd is al onsterfelijk. S. Widjaya, On Eclipse, http://blog.baliwww.com, d.d. 21.08.2008

43. Een herkenbaar detail is bijvoorbeeld de karbouw. 